\title{
KAJIAN HETEROTOPIA PADA PABRIK GULA COLOMADU
}

\section{Kinayung Syafira Aratuza}

Departemen Arsitektur, Fakultas Teknik, Universitas Indonesia (UI) Depok Jawa Barat, Indonesia

Email: aratuza96@gmail.com

\begin{abstract}
Abstrak
Tulisan ini dilatarbelakangi oleh perubahan fungsi yang terjadi pada Pabrik Gula Colomadu di Surakarta, yang awalnya hanya berfungsi sebagai pabrik gula dan sempat terbengkalai, saat ini terlah berubah menjadi bangunan komersial yang tetap mempertahankan sebagian besar fisik bangunan serta ruang dan alat produksi gula didalamnya, perubahan fungsi ini menyebabkan terjadinya pencampuran antara memori ruang di masa lalu dan ide ruang saat ini, yang bertujuan untuk ilmu pengetahuan dan ekonomi. Penelitian ini ingin membedah ruang lain atau heterotopia yang tercipta karena adanya penggabungan fungsi ruang, serta mengulas aspek-aspek yang menandai adanya ruang lain pada Pabrik Gula Colomadu. Penulis menggunakan pendekatan metode interpretasi historis yang menjelaskan penelitian berdasarkan bukti dan sudut pandang dari penulis dengan mengatur bukti kemudian diterjemahkan ke dalam narasi, dokumentasi foto dan cerita masa lalu tentang kondisi dan aktifitas pada pabrik gula colmadu sebagai bukti-bukti yang dapat ditelusuri secara sinkronik melalui studi literartur, serta alat untuk mengidentifikasi pabrik gula colomadu yaitu menggunakan enam prinsip heterotopia. Pabrik Gula Colomadu yang saat ini merupakan museum merupakan ruang publik yang dapat dinikmati oleh semua golongan masyarakat melalui prosedur tertentu, sekaligus 'ruang lain atau heterotopia' hasil refleksi dari berbagai aspek didalamnya, melibatkan memori, ide dan manusia.
\end{abstract}

Kata Kunci: heterotopia; pabrik gula colomadu; ruang lain

\section{Abstract}

This paper is motivated by the change in function that occurred at the Colomadu Sugar Factory in Surakarta, which originally only functioned as a sugar factory and was abandoned, currently turned into a commercial building that still maintains most of the physical building as well as the space and sugar production tools in it, this function change causes a mixture between the memory of the space in the past and the idea of the current space, Aimed at science and economics. This study wants to dissect other spaces or heterotopias created due to the incorporation of space functions, as well as review aspects that mark the existence of other spaces in the Colomadu Sugar Factory. The authors used photo documentation and past stories about the conditions and activities of the Colmadu sugar factory as evidence that can be traced in sync through literary studies, as well as identifying Colomadu sugar mills using the six principles of heterotopia. Colomadu Sugar Factory which is currently a museum is a public space that can be enjoyed by all groups of society

\footnotetext{
How to cite: $\quad$ Aratuza. K.S (2021) Kajian Heterotopia Pada Pabrik Gula Colomadu. Syntax Literate: Jurnal Ilmiah

Indonesia, 6(12). http://dx.doi.org/10.36418/ Syntax-Literate.v6i12.5047

E-ISSN: $\quad 2548-1398$

Published by: Ridwan Institute
} 
through certain procedures, as well as 'other spaces or heterotopias' resulting from reflections from various aspects in it, involving memory, ideas andhumans.

Keywords: heterotopia; colomadu sugarfactory; other space

Received: 2021-11-20; Accepted: 2021-12-05; Published: 2021-12-20

\section{Pendahuluan}

Pasca revolusi industri di Inggris, mesin-mesin uap mulai diperkenalkan, tidak ketinggalan juga dalam industri gula. Gula memang menjadi salah satu komoditi utama ekspor pada era Hindia Belanda, bahkan menempatkan Pulau Jawa sebagai produsen gula nomor dua setelah Kuba yang memenuhi perekonomian kolonial Belanda yang cukup dominan (Knight, 2014). Pabrik gula yang dibangun pada masa itu memang didominasi oleh Pemerintah Hindia Belanda, tetapi ada 1 pabrik gula yang lokasinya berada di Dusun Krambilan, Desa Malangjiwan, Kabupaten Karanganyar, Surakarta, yakni Pabrik Gula Colomadu yang dibangun oleh Bumiputera, yaitu Mangkunegara IV pada Minggu, 18 Desember 1861 yang pernah mengalami masa kejayaan bagi kerajaan dan telah menjadi sumber penghidupan juga sebagai identitas masyarakat (Wasino, 2014). Industri gula Mangkunegaran berpengaruh besar terhadap perkembangan ekonomi pedesaan sebagai sektor pangan dan peluang kerja bagi masyarakat (Wasino, 2008). Pabrik Gula Colomadu juga merupakan simbol dari modernisasi dan kemakmuran Bangsawan Jawa, biaya pembangunan Colomadu mencapai 4400.000 yang salah satu sumber modalnya berasal dari keuntungan perkebunan kopi milik Praja Mangkunegaran. Peralatan produksi gula didatangkan langsung dari Eropa. Nama Colomadu mengandung makna harapan agar kehadiran pabrik gula menjadi simpanan kekayaan dalam bentuk gula pasir yang menyerupai gunung.

Pabrik Gula Colomadu mulai beroperasi 1862, namun pada tahun 1946 pemerintahan Swapraja Mangkunegaran dihapus. Berakhirnya status pemerintahan Mangkunegaran membuat pabrik gula Colomadu diambil-alih pengelolaannya oleh pemerintahan RI atau dinasionalisasi dan diambil alih oleh Perusahaan Perkebunan Republik Indonesia (PPRI), kemudian berhenti beroperasi pada tahun 1998 karena kesulitan bahan baku dan krisis ekonomi yang membuat keuntungan penjualan gula tidak dapat menutupi biaya produksi yang sebenarnya (Wasino, 2008). Kemudian selain dikonsumsi sendiri dijual ke Belanda, Singapura dan Bandaneira, hasil keuntungan penjualan Pabrik Gula Colomadu digunakan Mangkunagoro IV untuk menggaji pegawai, merenovasi Puro Mangkunegaran, mendirikan sekolah rakyat, membangun sarana irigasi, dan jalan untuk kepentingan keluarga dan rakyat, Pabrik Gula Colomadu menjadi sebuah tempat yang sangat penting dan bermanfaat bagi masyarakat Desa pada saat itu, sehingga menyimpan banyak makna dan nilai-nilai sejarah di dalamnya. Pabrik Gula terbengkalai sampai tahun 2015, kemudian muncul ide revitalisasi oleh pemerintah dengan tujuan agar generasi sekarang tidak melupakan sejarah, bahwa Indonesia dulunya merupakan penghasil tambang 'emas' manis (gula). Pada 2017 Pabrik Gula Colomadu direvitalisasi dan dijadikan museum dengan namanya diubah menjadi De 
Tjolomadoe, membuat Pabrik Gula Colomadu memiliki ruang, makna dan nilai yang lain. Perubahan dan transisi yang terjadi dari abad ke 19, 2015 dan saat ini, menciptakan makna dan fungsi yang berbeda disetiap waktunya.

Pabrik gula Colomadu menandai bahwa politik dan kultur keraton tidak saja mengandalkan pembiayaan dari pajak, namun juga dari industri. Lebih dari itu, pabrik gula dihubungkan oleh rel-rel kereta api. Rel- rel tersebut menjadi simbol kemajuan, mengubah paradigma berpikir manusia Jawa tentang transportasi, dari tenaga hewan (kuda-kerbau) ke mesin-mesin dan teknologi terbarukan. Pabrik gula Colomadu yang mentrasformasikan Solo sebagai kawasan industri, menciptakan sebuah ruang berisi memori serta sejarah yang penting bagi Kota Solo.

Membicarakan ruang menjadi sama pentingnya dengan membicarakan bagaimana manusia memaknai relasi produksinya, Henri Lefebvre dalam bukunya The Production of Space (1991) menyebut hubungan antara ruang dan manusia sebagai Praktik Spasial. Dalam argumentasi Lefebvre "ruang adalah sebuah konsekuensi logis dari peradaban" ruang ada karena sebab-akibat yang terjadi dari masa ke masa, mengalami penyesuaian ataupun perubahan. Selain itu terdapat ruang-ruang yang ada namun sebenarnya tidak pernah ada, atau "ruang yang liyan" atau "yang lain", yaitu ruang (space) yang tampak dan membentuk cakrawala pengetahuan manusia, mengonstruksi pengetahun ruang dan sistem (kuasa atau apa) dari struktur pengetahuan itu sendiri, bukanlah sebuah inovasi melainkan sebuah produk dari historisitas (Foucault, 1967). Secara historis sejak Abad Pertengahan, peradaban Barat telah menyusun hierarki ruang sedemikian rupa: ruang sakral (gereja dan tempat ibadah) dan ruang profan (seperti pasar dan kedai minum), ruang publik (alun-alun kota) dengan ruang privat (istana raja), desa (rural) dan kota (urban), langit dan bumi, hingga surga dan neraka. Ruang diciptakan dalam memenuhi kebutuhan dan keinginan untuk menciptakan sesuatu yang ideal (utopis).

Istilah Utopia pertama kali dikemukakan oleh (More, 1974) dengan memecah dua kata Yunani : eutopia (tempat yang baik) dan ou-topia (bukan tempat/ tidak dimanapun juga), Utopia yang dimaksud More adalah tempat yang baik yang tidak berada dimanapun juga. Mencipatkan ruang yang ideal seringkali dianggap sebagai sesuatu yang utopis, menciptakan ruang yang sempurna. Sama halnya dengan pengertian Utopia menurut Foucault, yaitu sebuah situs tanpa tempat atau lokasi geografis yang nyata, namun memiliki relasi langsung (dan terkadang sekaligus berkebalikan) dengan ruangruang lain yang sesungguhnya ada dalam masyarakat, mewakili masyarakat itu sendiri dibawa ke kesempurnaan, atau kebalikannya, dan dalam hal apapun utopia adalah ruang yang pada dasarnya tidak nyata (Leach, 1997).

Perwujudan ruang yang utopis yang disebut Heterotopia, Heterotopia merupakan sebuah konsep yang merujuk pada situasi dan tempat berbagai utopia secara simultan termanifestasi ke dalam berbagai wujud representasi, dapat diterapkan sebagai metode dalam menggunakan ruang sebagai material semata atau sebagai mesin retorika (Faubion, 2008). Heterotopia merupakan bentuk aktualisasi ruang dan tempat yang utopis, tempat dimana yang biasa memenuhi hal luar biasa dalam kondisi-kondisi 
keserempakan, penjajaran, ambivalensi dan penyebaran. Heterotopia merupakan tempat yang berbeda, tempat yang dibangun dalam hubungannya dengan tempat lain.

Pabrik Gula Colomadu yang kini merupakan museum merupakan bangunan yang sangat menarik untuk ditelusuri perubahan serta percampuran ruang yang ada di dalamnya. Sudah cukup banyak peneliti yang menjadikan pabrik gula colomadu sebagai topik penilitian khususnya dalam ranah sejarah (revitalisasi) dan arsitektural (elemen interior, struktur, material dan identitas), namun tidak penulis temukan yang secara spesifik membahas kedalaman makna ruang dan waktu yang menciptakan heterotopia dalam perjalanannya dari berdiri hingga saat ini, seperti ruang-ruang dalam museum yang tersusun atas potongan-potongan memori dan waktu sehingga mampu menghadirkan 'of other space' atau heterotopia. Oleh sebab itu, tulisan ini bertujuan untuk melihat 'ruang lain' atau heterotopia pada ruang-ruang dalam museum De Tjolomadoe (Pabrik Gula Colomadu), dengan mengidentifikasinya berdasarkan enam prinsip Heterotopia.

Diharapkan melalui penelitian ini dapat meningkatkan kesadaran akan esensi ruang dan waktu dari bangunan Pabrik Gula Colomadu (De Tjolomadu) sebagai salah satu bangunan yang berpengaruh dan memiliki memori penting bagi Kota Solo. Serta sebagai pemicu bagi peneliti lain untuk mempelajari dan menggali kajian teori dan sejarah arsitektur dengan lebih seksama sehingga akan memunculkan isu-isu lain sebagai topik penelitian.

\section{Metode Penelitian}

Tulisan ini menggunakan pendekatan metode dari Linda Groat dan David Wang mengenai metode interpretasi historis, menjelaskan metode penelitian dalam sejarah yaitu selain bukti masa lalu sudut padang dari sejarawan menjadi kunci dari penelitian, dengan mengatur bukti-bukti yang ada kemudian diterjemahkan ke dalam narasi untuk menguatkan obyektifitas dan interpretasi peneliti. Sejarah pada dasarnya adalah sebuah hipotesis dari kejadian-kejadian yang telah terjadi, rekonstruksi sejarah akan nyata jika penelitian ditulis secara ilmiah dengan metodis dan sistematis.

Bukti-bukti penelitian dikumpulkan dengan melakukan studi literatur dan arsip yang membahas serta berhubungan dengan teori dan wacana yang terkait pokok bahasan yaitu perubahan Pabrik Gula Colomadu serta fungsi dan aktivitas di dalamnya. Data yang dikumpulkan berasal dari sumber-sumber yang terdiri dari peta sebagai alat tektualisasi dari realitas spasial. Dokumentasi foto untuk menggambarkan hubungan antara perilaku manusia dengan ruang. Menelusuri masa lalu adalah pendekatan yang dipilih untuk mengungkap dan menjelaskan perubahan, perkembangan, serta menganalisis dan mengkaji keterkaitan ruang pada Pabrik Gula Colomadu terhadap enam prinsip Heterotopia yang disebut juga Heterotopology. Enam prinsip tersebut, antara lain : 1) Crisis dan Deviation : (a) Heterotopia of crisis: tempat yang memiliki hak-hak isti-mewa (khusus), sakral atau terlarang, yang disediakan bagi individu yang, dalam kai-tannya dengan lingkungan manusia dimana mereka tinggal, dalam kondisi krisis; (b) heterotopia of deviation: dimana individu ditempatkan karena perilaku 
mereka yang menyimpang dalam hubungan yang dimak-sudkan atau norma yang diwajibkan dalam masyarakat, bersantai merupakan suatu kebiasaan; 2) Function : Suatu tempat yang memiliki fungsi yang tepat dan telah ditentukan dalam masyarakat (Johnson, 2013). Atau suatu tempat dengan fungsi tertentu sebagai suatu tempat dalam sebuah masyarakat (Slunecko, 2009); 3) Juxtaposition : Keberagaman ruang dalam suatu tempat tunggal yang nyata: serang-kaian ruang di dalam suatu tempat yang asing satu sama lain (Slunecko, 2009). Mengidentifikasi epistemologi sebagai ruang konseptual yang dapat dipahami secara utuh, kesatuan, sejajar tanpat harus dipisahkan (Mary, 2012), Serta memiliki kekuatan untuk menempatkan secara ber-dampingan beberapa tempat dalam suatu tempat tunggal yang nyata (Johnson, 2013); 4) Time (heterochronism) : Berkaitan dengan akumulasi (irisan) waktu dalam satu tempat yaitu 'waktu tradional' berupa rutinitas dalam kehidupan keseharian. Ber-beda dengan akumulasi waktu, sebalik-nya, terkait dengan waktu yang temporer dan musiman (Johnson, 2013); (Slunecko, 2009); Selain itu menggambarkan lapisan spasial dan temporalitas yang tumpang tindih yang dapat diamati secara visual dari berbagai ruang dan waktu (Chung, 2018); 5) Place : Heterotopia selalu mensyaratkan sistem buka dan tutup, baik untuk mengisolasikannya dan mem-buatnya dapat dimasuki (Johnson, 2013). Tetapi ada heterotopia lainnya yang seharusnya menjadi 'ruang yang dibagi dan kolektif', terbuka untuk publik dan dapat diakses (Iliopoulou, Kepaptsoglou, \& Karlaftis, 2015); 6) Society : Mereka memiliki peran untuk menciptakan ruang ilusi yang mengekspos semua ruang yang nyata, atau sebaliknya menciptakan ruang lain, ruang nyata lain, yang sempurna dan sangat teliti (Johnson, 2013). Koloni khusus dari masyarakat yang beroperasi dalam irama yang sama, kebiasaan, kewajiban, kesa-maan maksud/ tujuan/ kepentingan, suka, tidak suka dan sebagainya. Masyarakat dalam suatu tempat dapat menjadi 'ilusi' bagi orang dan/ atau pengunjung yang lewat secara acak (Slunecko, 2009).

\section{Hasil dan Pembahasan}

\section{Analisis dan Interpretasi}

a. Pabrik Gula Colomadu 1861 - 1998

Lokasi Pabrik Gula Colomadu terletak tepat di Desa Malangdjiwan pada awalnya merupakan daerah pertanian terlihat pada peta topografi, yang kemudian berkembang menjadi sasaran pendirian pemukiman penduduk. Hal ini terjadi akibat semakin tingginya tingkat pertumbuhan penduduk dan kepadatan penduduk di Kota Surakarta, serta pengaruh dari beridirinya pabrik gula. Pabrik Gula Colomadu merupakan sebuah kawasan pabrik yang tidak hanya terdapat bangunan pabrik namun dilengkapi dengan area perkebunan tebu kantor administrasi, area perumahan pegawai dan area perumahan pekerja, yang menciptakan struktur kehidupan bermasyarakatnya sendiri, pabrik ini juga dilalui oleh jalur kereta api yang menghubungkan Malangdjiwan dengan daerah-daerah lainnya. (gambar 1). 


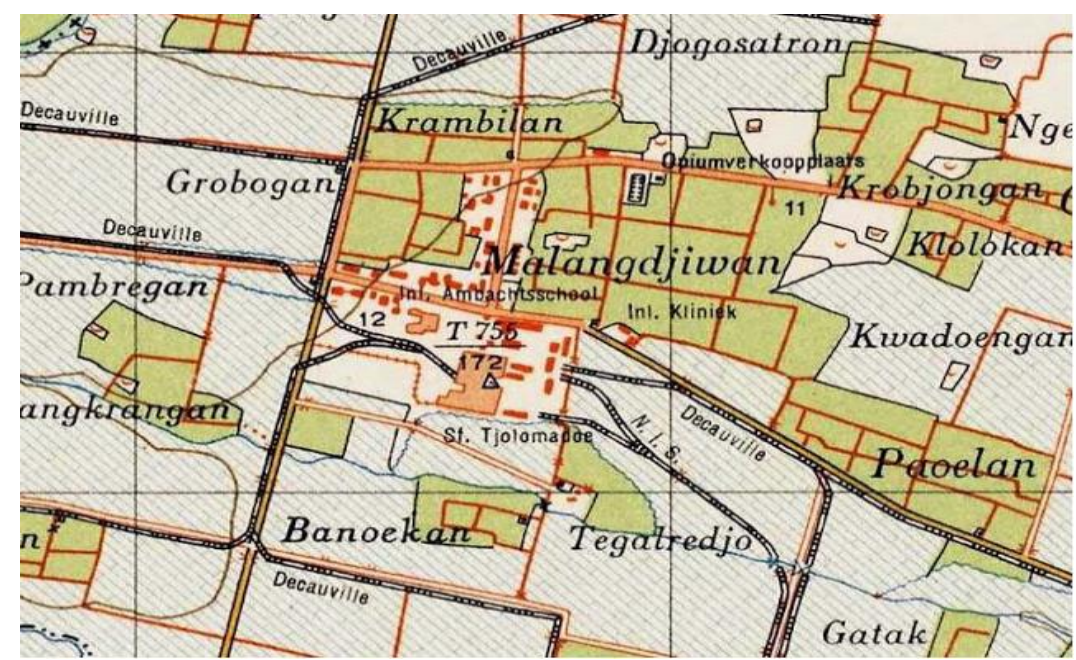

Gambar 1

Peta Topografi, 1932

Sumber: Leiden University

Pabrik Gula Colomadu berfungsi sebagai tempat pengolahan tebu menjadi gula yang kemudian digunakan sendiri dan dipasarkan. Hasil dari produksi tebu ini selain digunakan untuk menggaji pegawai dan memperbaiki pabrik, juga digunakan untuk keperluan daerah sekitar seperti membangun sekolah. Banguan Pabrik Gula Colomadu ini di desain dengan langgam arsitektur kolonial ditandai dengan jendela-jendela yang tinggi dan berbentuk setengah lingkaran pada bagian atasnya, atap pabrik juga dibuat cukup tinggi karena mesin-mesin pengolah tebu yang sangat besar. Pabrik Gula Colomadu yang awalnya hanya terdiri dari dua bangunan dan cerobong asap, mengalami perkembangan yang sangat baik, terlihat dari penambahan bangunan pada bagian depan dan penambahan tinggi cerobong asap, perubahan bangunan ini menandai perkembangan pabrik gula colomadu yang cukup pesat (gambar 2).
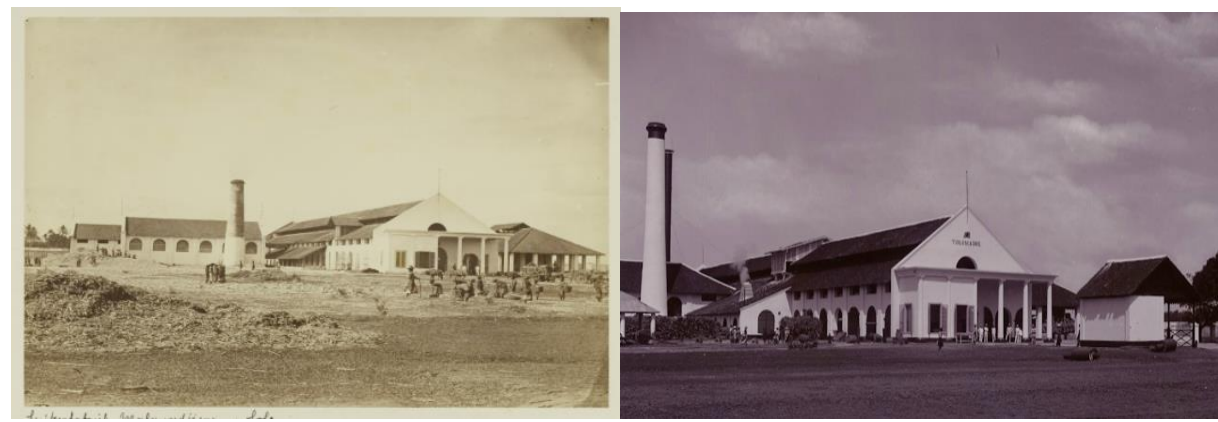

Gambar 2

Pabrik Gula Tjolomadoe, Circa 1867 dan 1928

Sumber : KITLV 
b. Pabrik Gula Colomadu 1998 - 2015

Pabrik Gula Colomadu pada masa pendudukan jepang menjadi titik kehancuran dengan adanya aksi bumi hangus seperti bangunan dan alat produksi. Jenis perkebunan yang diutamakan oleh Jepang adalah tanaman untuk perang seperti jarak, kapas dan rami (Permatasari, 2008) setelah ditutup menjadi masamasa yang penting untuk dikaji, karena meninggalkan memori bagi sebagaian orang. Bangunan pabrik pengolahan pada tahun 2015 merupakan hasil perluasan yang dilakukan pada tahun 1928. Tampak depan bangunan pabrik yang telah ditinggalkan dan tidak terurus ini warna cat dindingnya telah memudar, bahkan digantikan dengan lumut, jendela dan kayu telihat lapuk, besi-besi pada jendela dan pintu juga telah berkarat, bangunan masih lengkap dengan adanya cerobong asap dan menara air yang terlihat usang, namun hal itu tidak menutup kemegahan dan keunikan desain dari Pabrik Gula Colomadu (gambar 3). Bagian-bagian pabrik masih dapat terlihat jelas berdasarkan mesin-mesin yang masih berdiri kokoh, ruang pada pabrik colomadu dibagi berdasarkan jenis kerjanya, yaitu Stasiun Gilingan yang letaknya paling depan, Stasiun Pemurnian, Stasiun Penguapan Nira, Stasiun Masakan, Stasiun Putaran, dan Stasiun Penyelesaian. Bagian dalam pabrik cukup mengenaskan, melihat mesin-mesinnya masih tersisa disetiap sudut pabrik sudah usang dan karatan, dari tanaman liar yang merambah masuk ke dalam pabrik hingga atap seng yang lapuk dan berlubang. (gambar 4).

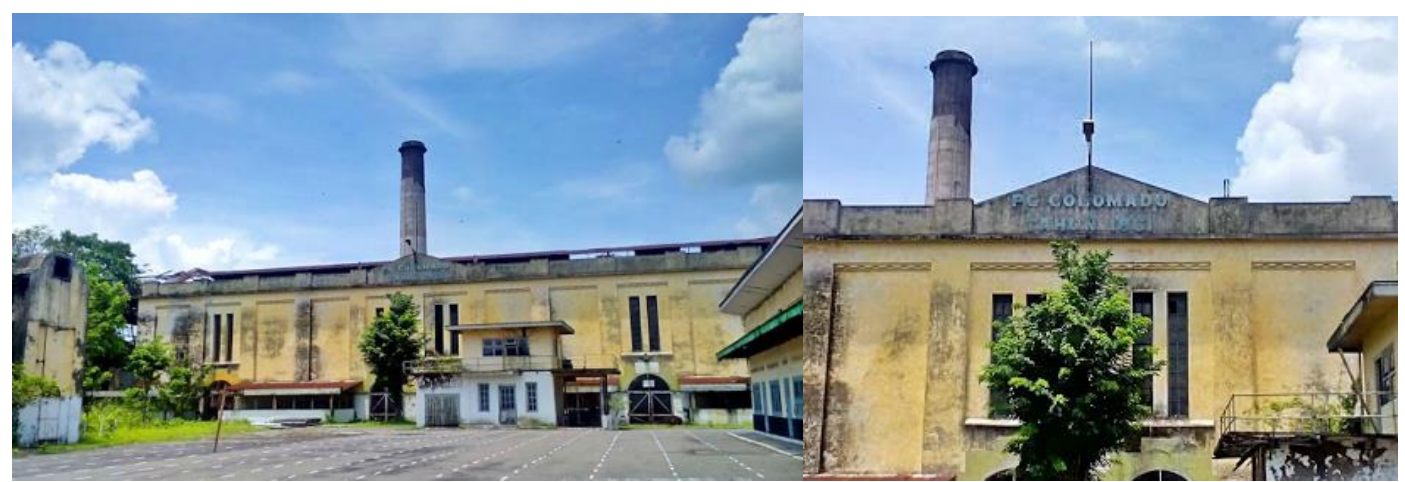

Gambar 3

Bagian dalam Pabrik Gula Colomadu, 2015

Sumber: jejakkolonial.com 

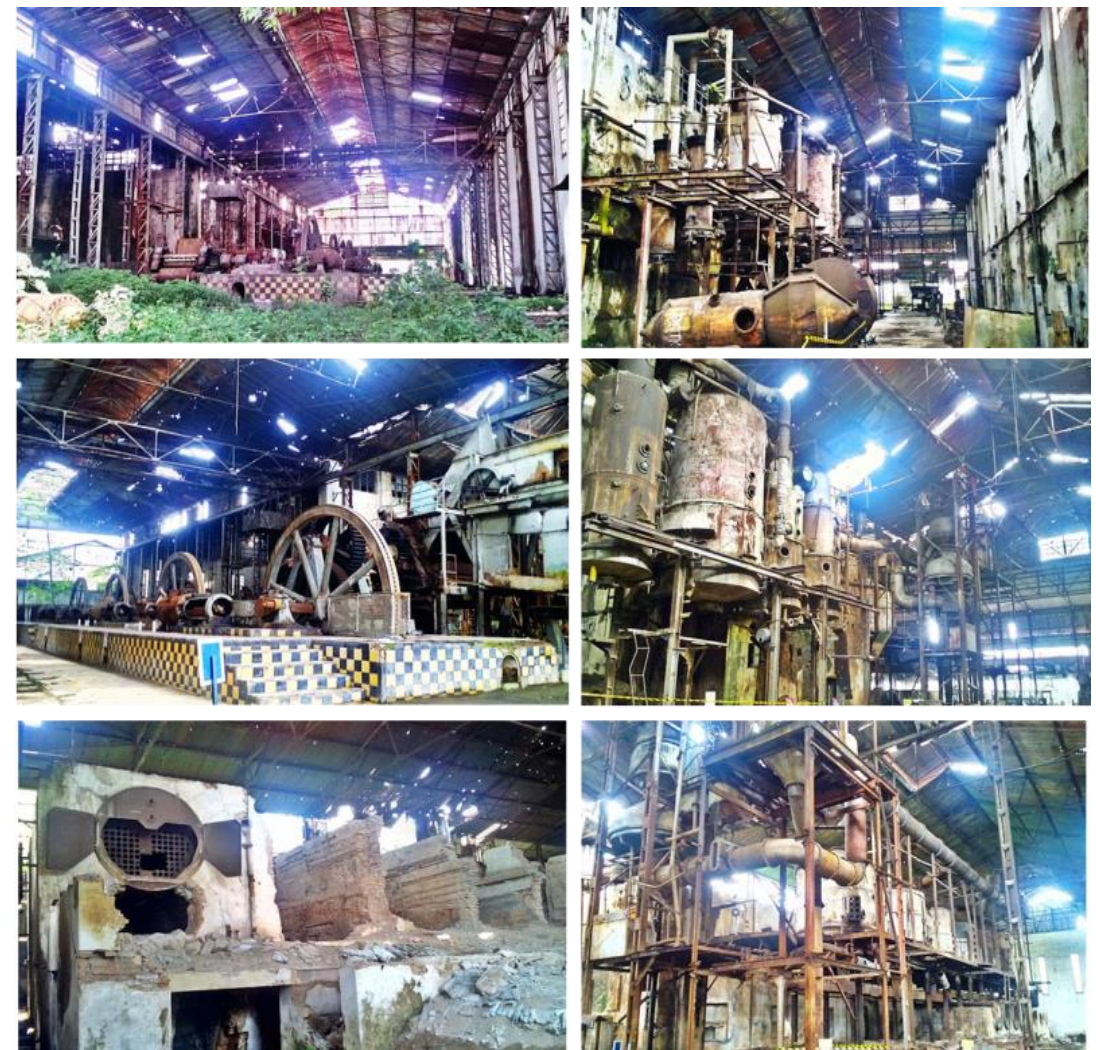

Gambar 4

Bagian dalam Pabrik Gula Colomadu, 2015

Sumber: jejakkolonial.com

Namun bagi segelintir orang penampakan seperti ini sangat menarik dan semakin memperlihatkan sisi historisnya, sehingga meskipun diterlantarkan oleh pemerintah setempat, Pabrik Gula Colomadu masih dikunjungi oleh orang-orang yang tertarik dengan sejarah, orang-orang yang ingin melakukan uji nyali (PG Colomadu dimaknai sebagai tempat yang angker), dan orang-orang sastra yang melakukan pegelaran seni berjudul "Fabriek Fikr" di dalam pabrik ini, walau mesin-mesin terlihat usang namun mampu memberikan ilham dan inspirasi bagi segelintir seniman. Bahkan dengan kehilangan fungsinya sebagai tempat pembuatan gula, PG Colomadu kembali memberikan makna lain (gambar 6). Berdasarkan hal ini terlihat utopia diciptakan melalui pagelaran seni yang menjadikan Pabrik Gula sebagai inspirasi, mencoba menyatukan antara seni (teater, puisi, tari dan musik modern) dengan pabrik tua yang terabaikan, menjadikannya sebuah panggung pertunjukan seni, sehingga menciptakan representasi ruang lain. 


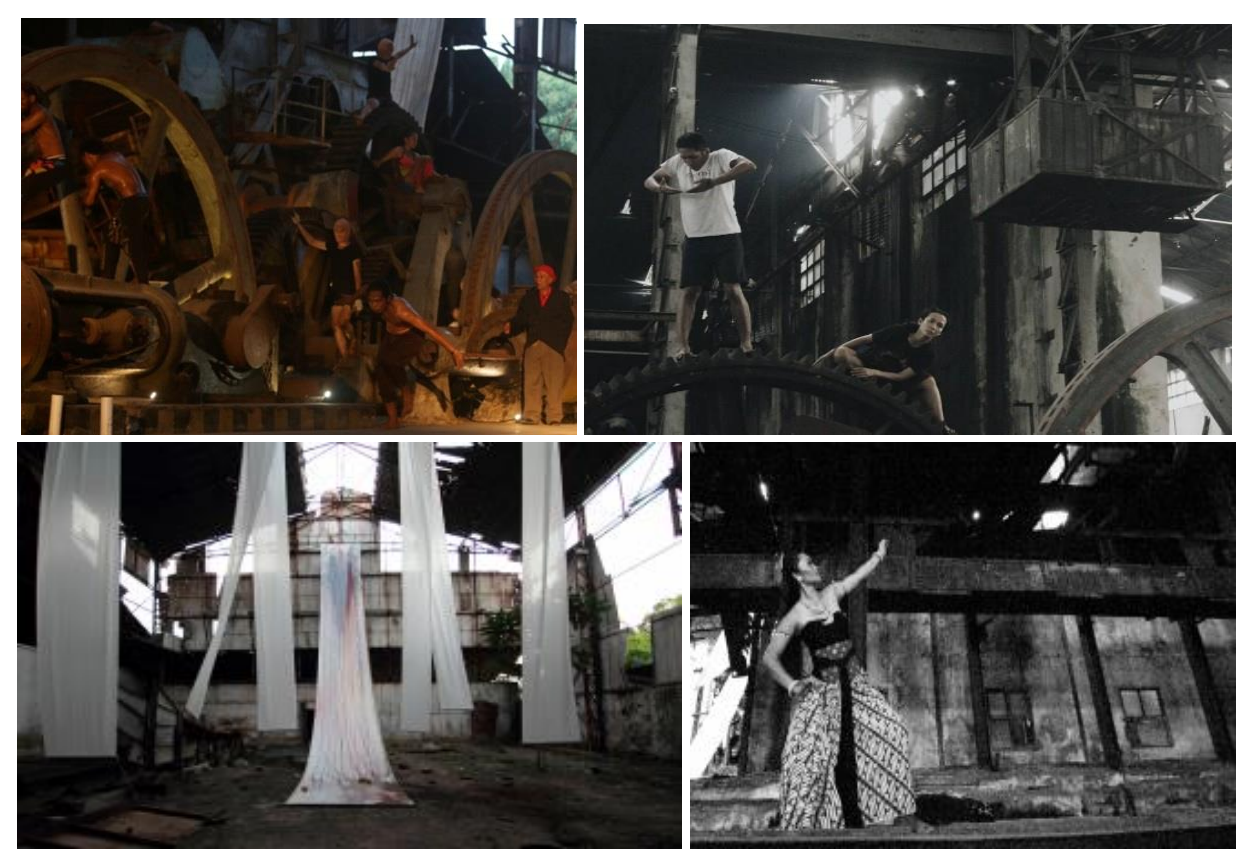

Gambar 5

Pagelaran Seni “Fabriek Fikr" di Pabrik Gula Colomadu, 2015

Sumber: google.com

c. Heterotopia dalam Pabrik Gula Colomadu saat ini

Pemerintah melakukan peletakan batu pertama atas revitalisasi Pabrik Gula Colomadu. Rencananya, bangunan bekas pabrik gula tersebut akan dijadikan pusat kebudayaan di Jawa Tengah, rencana revitalisasi tersebut dapat dilihat dari masterplan Pabrik Gula Colomadu. Ruang yang digunakan dalam proses pembuatan gula tetap dipertahankan, selain itu terdapat penambahan area parkir, cafe dan hall yang disewakan untuk berbagai kegiatan (gambar 7). Bekas bangunan seluas 1,3 hektare disulap menjadi ruang publik, tapi tak menanggalkan bentuk atau bagian-bagian asli pabrik gula pada masanya, mesin-mesin, cerobong asap, menara air serta beberapa bagian masih dipertahankan dengan kondisi material dan cat yang lebih baik (gambar 8). Nama-nama ruang di dalamnya tetap dipertahankan, seperti Stasiun Gilingan yang difungsi kan sebagai museum pabrik gula, Stasiun Ketelan sebagai area kantin, Stasiun Penguapan sebagai area arcade, Stasiun Karbonatasi sebagai area art dan craft, Besali Café sebagai restoran, serta Tjolomadoe Hall atau ruang konser, dan Sarkara Hall sebagai pelataran multifungsi. Revitalisasi De Tjolomadoe mempertahankan desain fasad bangunan yang khas, selain itu arsitekturnya memadukan unsur heritage dan modern dengan perpaduan industrial-finished. De Tjolomadoe tetap mempertahankan bentuk eksisting bangunan PG Colomadu dengan menambah transfer beam untuk memperkuat struktur. 


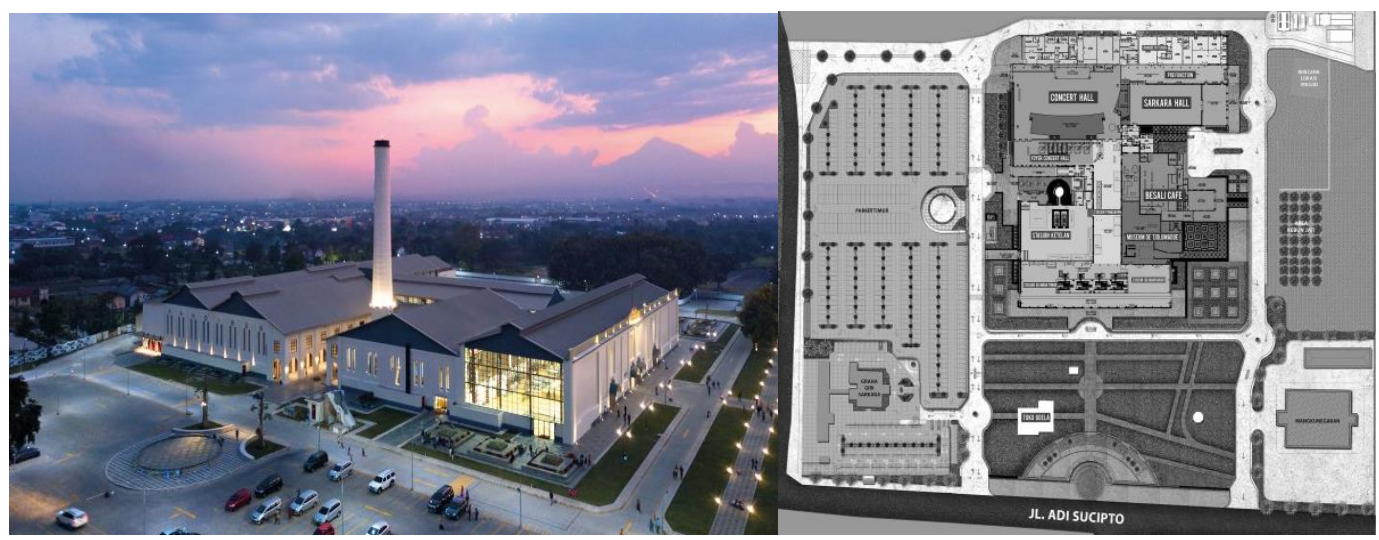

Gambar 6

Perencanaan Revitalisasi dan Masterplan Pabrik Gula Colomadu (selesai pada 2018)

Sumber: constructionplusasia.com

Sebuah utopia yang diciptakan dengan mencoba menyatukan antara Pabrik Gula di masa lalu (museum) dengan kemajuan teknologi dan kebutuhan masa sekarang (café dan hall), membawa kembali ingatan pada saat masa kejayaan sebagai Pabrik Gula, adanya upaya dalam menyempurnakan bangunan, menjadikannya multifungsi dari segi pendidikan dan komersial. Kemudian menciptakan ruang lain atau heterotopia.

d. Crisis \& Deviation

Dalam esay The Metropolis and Mental Life dari Georg Simmel yang menjelaskan mengenai kehidupan pada kota modern, Simmel menjelaskan kondisi psikologis masyarakat perkotaan yang membutuhkan tempat untuk melepaskan depresi dan kegelisahan, sehingga De Tjolomadoe hadir sebagai bangunan komersial sekaligus tempat untuk melepas lelah, jenuh, bosan akan rutinitas keseharian dengan berbagai macam fungsi yang ditawarkan didalamnya yaitu museum, cafe, glow in the dark room dan sebagainya (gambar 8).

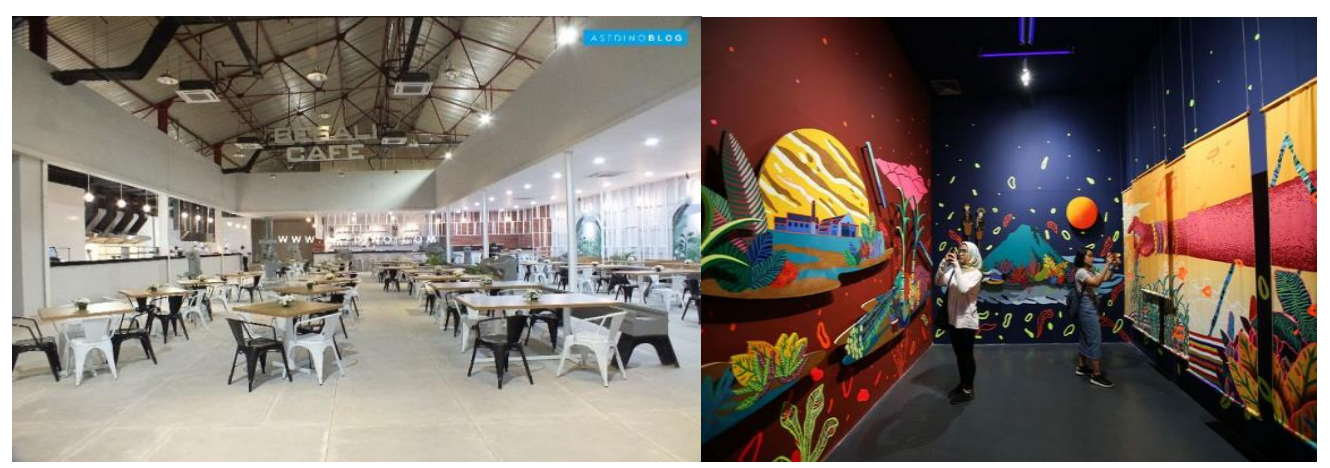

Gambar 7

Area café dan ruangan modern 'glow in the dark'

Sumber: constructionplusasia.com 
e. Function

De Tjolomadoe memiliki fungsi yang tepat dalam masyarakat yaitu sebagai ruang publik yang digunakan untuk beragam aktivitas pendidikan, sosial dan ekonomi. Ruang publik yang terbuka dan bisa diakses seluruh lapisan masyarakat menjadi arena bagi terciptanya suatu kehidupan masyarakat yang di-utopiskan (Orum \& Neal, 2009). Bangunan ini tidak hanya memiliki satu fungsi saja, selain sebagai museum yang menampilkan masa kejayaan pabrik gulam bangunan ini juga terdapat hall yang disewakan untuk kegiatan seminar atau pernikahan, selain itu terdapat aktivitas ekonomi seperti café dan retail ynag menawarkan pernakpernik khas Kota Solo.

f. Juxtaposition

De Tjolomadoe mampu mensejajarkan beberapa fungsi ruang dalam satu tempat tunggal yang nyata, Heterotopia memiliki bentuk yang berbeda-beda tergantung pada konteks budaya, kurun waktu dan ruang yang berbeda. Aplikasi desain pada Stasiun-Stasiun di Pabrik Colomadu menggabungkan antara desain bangunan asli Pabrik (dinding, lantai, mesin pabrik), ornamen lampu jalan dengan desain klasik, dan pengaplikasian konsep modern industrial (mengekspose utilitas dan material).

De Tjolomadoe sebuah bangunan pabrik khas Eropa dengan ubin yang warnanya seperti pion catur. Mesin-mesin eksisting peninggalan pabrik gula tetap dipertahankan, lalu dilapisi cat khusus untuk mencegah karat sebagai bagian dari elemen arsitektur dan interior bangunan itu sendiri. Layout ruang dengan fungsi baru mengikuti denah eksisting saat masih berfungsi sebagai pabrik gula (gambar 9). Penamaan ruang pada fungsi baru mengikuti nama asli ruangan saat pabrik gula ini masih beroperasi. De Tjolomadu sendiri ada terbagi ke dalam 3 bagian, yakni Stasiun yang berada di gedung bekas PG Colomadu serta Hall (Tjolomadoe Hall dan Sarkara Hall). Di dalam gedungnya, terdapat 4 stasiun, yakni: Stasiun Gilingan, Stasiun Ketelan, Stasiun Penguapan dan Stasiun Karbonatasi, yang difungsikan sebagai museumnya adalah Stasiun Gilingan, terdapat gilingan tebu yang sangat besar, serta memuat sejarah PG Colomadu dibangun, miniatur proses pengolahan gula, baju pegawai, mesin ketik, blue print PG Colomadu, hingga foto-foto PG Colomadu dari abad ke-19 (gambar 10). 


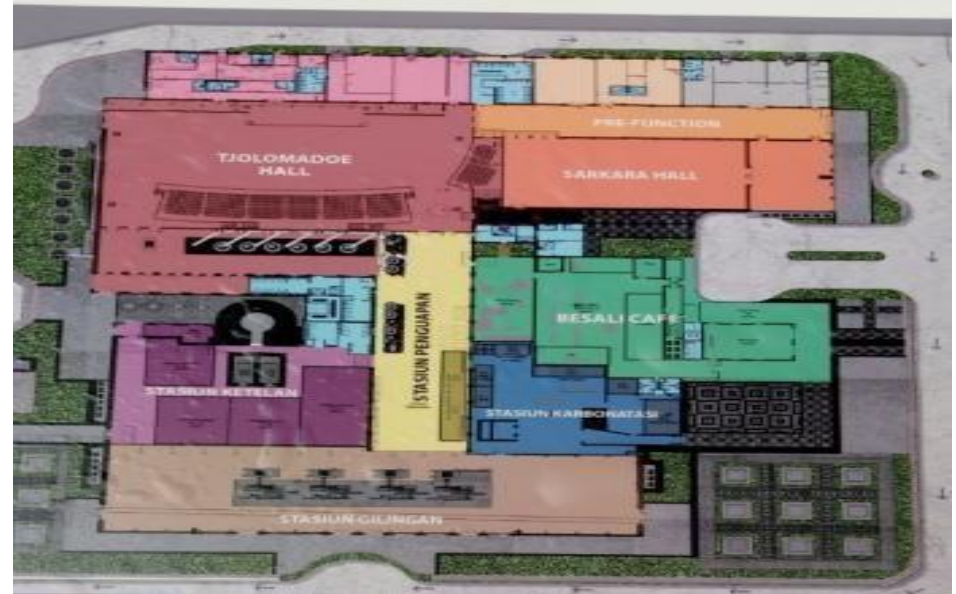

\section{Gambar 8}

Denah de Tjolomadoe, 2017

Sumber: constructionplusasia.com

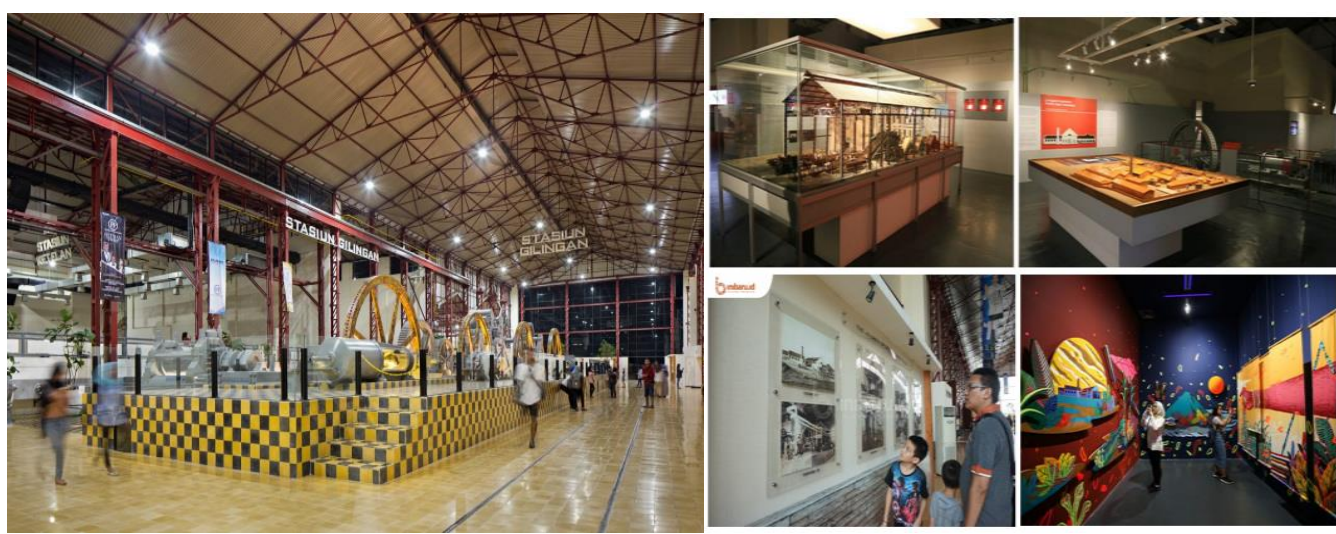

\section{Gambar 9}

\section{Stasiun Gilingan De Tjolomadoe}

Sumber: google.com

Kemudian, Stasiun Penguapan yang di dalamnya terdapat mesin-mesin penguapan dan area sekitarnya merupakan deretan café dan store. Di Stasiun ini mesin penguapan pada masa Hindia Belanda yang telah dipoles disandingkan dengan dengan desain modern dari retail-retail serta penambahan lampu jalanan dibagian tengah. Desain jendela, lantai dan rangka atap masih masa seperti sebelumnya (gambar 11). Di dekat Stasiun Penguapan, terdapat pintu yang diatasnya tertera Stasiun Ketelan, Area Stasiun Ketelan ini terdapat Art and Craft dan café. Di area ini terdapat tempat Ketel Tekanan Rendah, yakni ada dua besi berbentuk bulat bolong-bolong tertempel pada tembok. Stasiun Ketelan terhubung langsung dengan Cerobong Asap (gambar 12). 


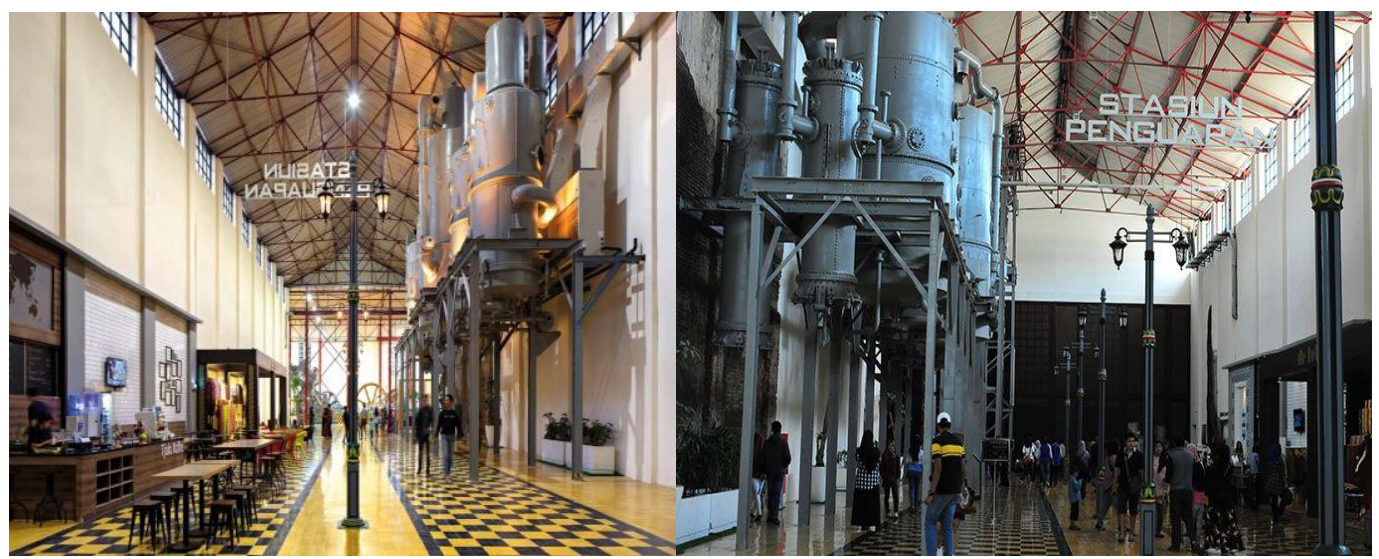

Gambar 10

Stasiun Penguapan De Tjolomadoe

Sumber: google.com

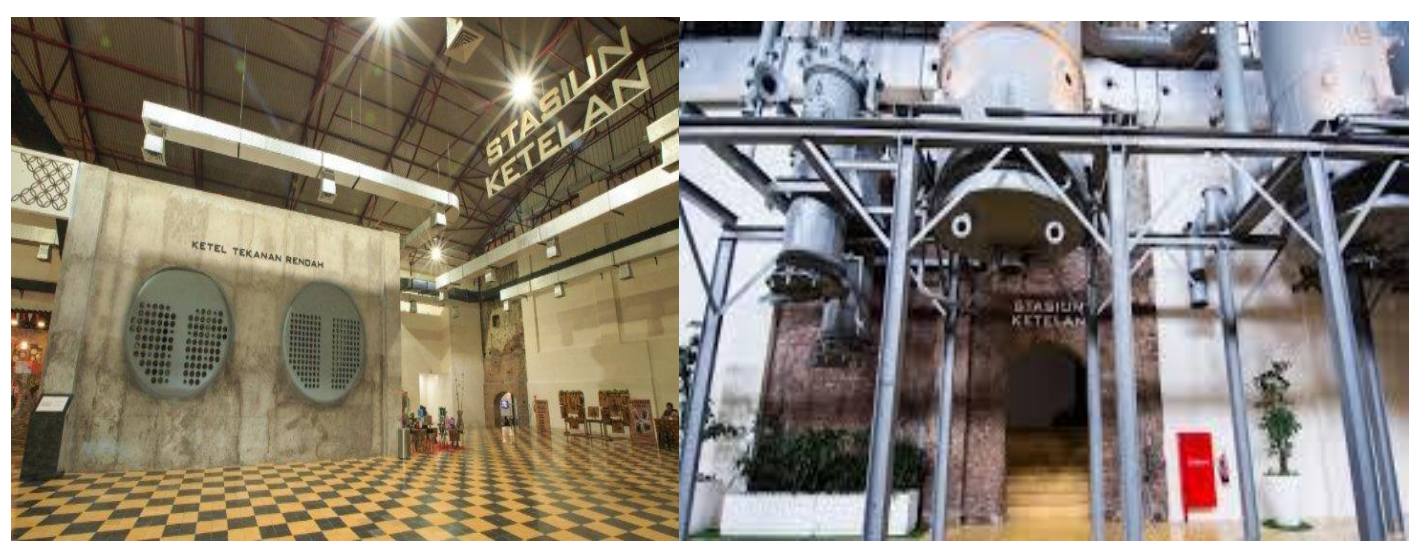

Gambar 11

Stasiun Ketelan, De Tjolomadoe

Sumber: google.com

Di bagian belakang Stasiun Penguapan, masih ada stasiun lagi yang terlupakan, yakni Stasiun Karbonatasi, area sekitarnya yang dibuat menjadi tempat berjualan souvenir seperti pernak-pernik dan batik. Di stasiun ini terdapat alat karbonatasi untuk akhir proses tebu menjadi gula menyatu dengan sistem pengudaran yang modern dilangit-langitnya (gambar 13) heterotopia juga terlihat pada cerobong asap dan menara air pabrik gula colomadu, bentuk fisiknya yang tetap sama, namun mencoba memasukan imaginasi tentang bagimana bangunan ini terlihat di masa lalu dengan memperbaharui cat dan mengatasi karat (gambar 14). 


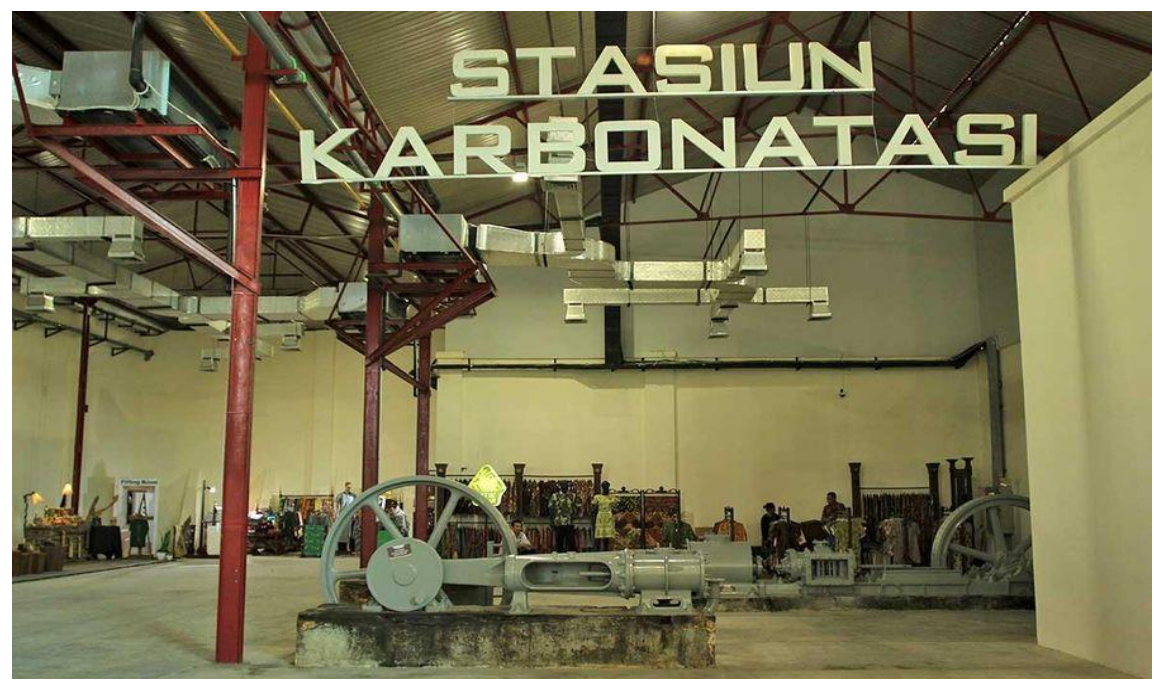

Gambar 12

Stasiun Karbonatasi, De Tjolomadoe

Sumber: google.com
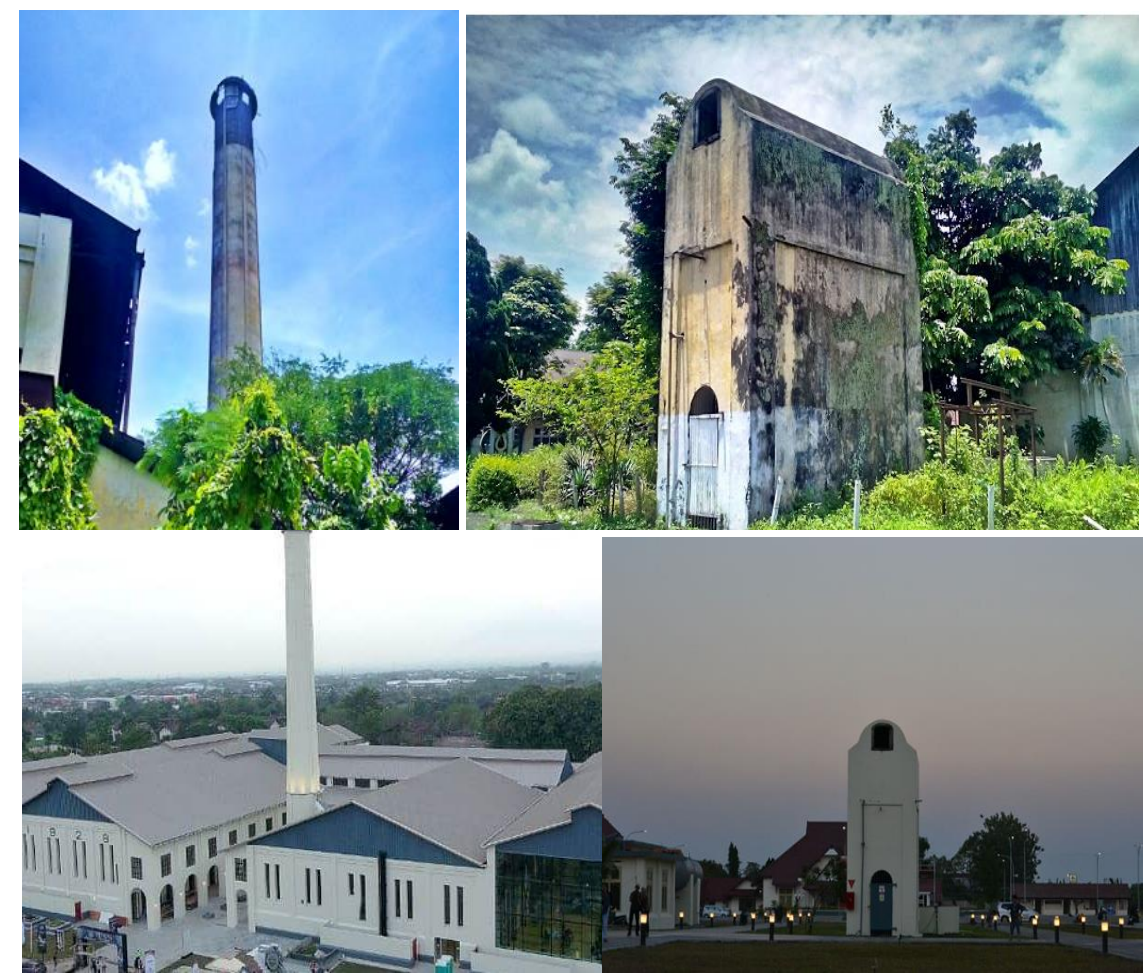

Gambar 13

Cerobong Asap dan Menara Air Pabrik Gula Colomadu 2015 (atas) dan 2019 (bawah)

Sumber: jejakkolonial.com

Heterotopia terdapat didalam satu ruang yang mampu mengadirkan dan menyatukan dua buah representasi waktu yang berbeda, masa lampau dan masa sekarang. Heterotopia terbentuk dengan mencoba membuat hubungan dari potongan-potongan waktu, membagi area museum dengan stasiun-stasiun 
berdasarkan pada interpretasi tentang bagaimana pabrik bekerja, sehingga menjadi kesatuan atau alur proses dalam pengoalan tebu menjadi gula. Pabrik gula colomadu diubah menjadi sebuah tempat yang tersusun dari beragam waktu yang sebenarnya berada di luar sifat waktu itu sendiri, dan untuk mengorganisir dengan cara mengabadikan dan membuat akumulasi waktu dan ruang tak bergerak menjadi tidak terbatas.

g. Time (heterochronism)

Heterotopia memulai fungsinya secara pe-nuh ketika individu-individu secara resmi menemukan dirinya sendiri di dalam suatu jenis pemutusan total/ absolut dari waktu tradisional mereka atau rutinitas. De Tjolomadoe sebagai ruang publik yang dapat dirasakan manfaatnya ketika masyarakat melepaskan diri dari rutinitas kesehariannya dan masuk ke dalam temporalitas melalui initeraksi yang berbeda dengan apa yang dihadirkan oleh museum. De Tjolomadoe juga menunjukan tanda-tanda temporalitas karena sering kali digunakan untuk event tertentu (gambar 15).

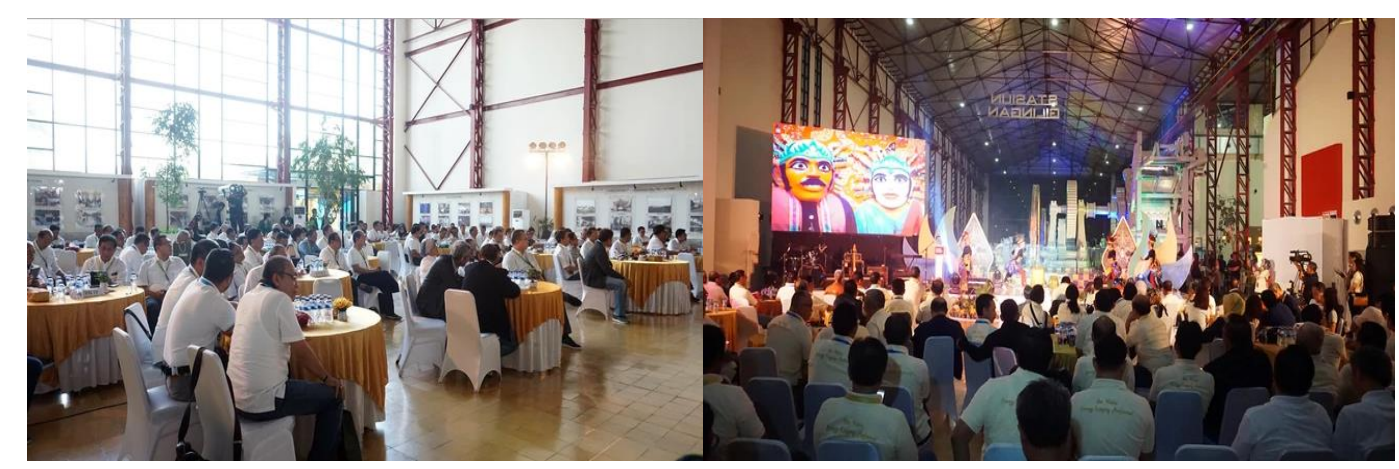

Gambar 14

Festival dan event temporal yang terjadi pada De Tjolomadoe Sumber: detjolomadoe.com

h. Place

Heterotopia diasumsikan sebagai sebuah sistem bukaan dan penutupan yang keduanya bisa di isolasi dan ditembus. Pintu-pintu masuk tiap stasiun ini sebagai tanda fisik utama terjadinya perubahan aktivitas yang saling terhubung, bukaan terjadi saat memasuki stasiun dengan, penutupan terjadi saat akan perpindah ke stasiun lain. Selain itu, untuk memasuki area museum sebelumnya harus melewati pintu depan untuk membeli tiket masuk, area museum juga dijaga oleh 4-5 orang disetiap ruangnya. Area museum ini 'sebenarnya' secara simultan menyembunyikan pengecualian yang 'menggambarkan kondisi yang lainnya' seperti yang dikatakan oleh (Foucault, 1967) pembatasan-pembatan seperti ini yang dimaksudkan bahwa ada gesture khusus untuk dapat masuk ke tempat heterotopia, dalam hal ini area pembelian tiket masuk pada museum De Tjolomadoe. 


\section{i. Society}

Heterotopia menciptakan ruang ilusi yang mengedepankan ruangnya dalam gerak kehidupan manusia atau untuk menciptakan ruang nyata "yang lain" yang kelihatannya sempurna, rumit atau detail, teroganisir, padahal merupakan refleksi ruang nyata yang kacau, campur aduk, "sakit" dan "menyedihkan". Sebuah museum hanya akan menjadi ruang 'mati' tanpa adanya interaksi di dalamnya. Heterotopia merupakan manifestasi dari apa yang dipandang sebagai utopis, sehingga aktivitas yang terjadi mencerminkan suatu kondisi 'ideal' yang diharapkan, bagaimana pengelola mengatur alur manusia saat memasuki area museum, yang disesuikan dengan proses pengolahan tebu menjadi gula.

\section{Kesimpulan}

Ruang lain atau Heterotopia dapat dilihat pada Pabrik Gula Colomadu yang saat ini bernama De Tjolomadoe di Surakarta yang berfungsi sebagai Museum dan ruang publik yang bisa diakses oleh siapa saja namun dengan prosedur yang telah ditetapkan. Museum ini menghadirkan Ruang lain yang menggabungkan dan merefleksikan ide dengan realitas masyarakat akan kemungkinan kehidupan yang 'ideal' (utopia), berdasarkan identifikasi heterotopology yang dimiliki museum ini yaitu krisis dan penyimpangan, fungsi, penjajaran, waktu, tempat, dan masyarakat serta apa yang terjadi didalamnya semua berkontribusi dalam berbagai bentuk dan cara yang nyata dalam memproduksi ruang lain yakni heterotopia. Ciri heterotopia yang paling terlihat dari museum de tjolomadoe adalah mencoba membuat ruang 'ideal' dengan menyatukan memori masa lalu pabrik gula colomadu dengan ide/ imajinasi yang telah ada hingga saat ini, menyatukan sejarah pada masa keemasan pabrik gula colomadu dengan kondisi saat ini, sehingga sesuai dengan apa yang dibutuhkan oleh masyarakat modern. Sehingga, Museum De Tjolomadoe merupakan perwujudan dari prinsip heterotopia. 


\section{BIBLIOGRAFI}

Chung, Hye Jean. (2018). Media Heterotopias: Digital Effects and Material Labor in Global Film Production. Duke University Press. Google Scholar

Faubion, James D. (2008). Heterotopia: an ecology. In Heterotopia and the City (pp. 43-52). Routledge. Google Scholar

Foucault, Michel. (1967). La grammaire générale de Port-Royal. Langages, (7), 7-15. Google Scholar

Iliopoulou, Christina, Kepaptsoglou, Konstantinos, \& Karlaftis, Matthew G. (2015). Google Scholar

Route planning for a seaplane service: The case of the Greek Islands. Computers \& Operations Research, 59, 66-77. Google Scholar

Johnson, Peter. (2013). The geographies of heterotopia. Geography Compass, 7(11), 790-803. Google Scholar

Knight, G. Roger. (2014). The sugar industry of colonial Java and its global trajectory. South East Asia Research, 8(3), 213-238. Google Scholar

Leach, Neil. (1997). Rethinking architecture. Taylor \& Francis Limited. Google Scholar

More, Thomas. (1974). Thomas More. Weidenfeld. Google Scholar

Orum, Anthony M., \& Neal, Zachary. (2009). Common ground?: readings and reflections on public space. Routledge. Google Scholar

Slunecko, Thomas. (2009). Balancieren-eine Einladung zur Übergegensätzlichkeit. na. Google Scholar

Wasino. (2008). Kapitalisme Bumi Putra: Perubahan Masyarakat Mangkunegaran. Yogyakarta: LKIS.

Wasino. (2014). Modernisasi di Jantung Budaya Jawa, Mangkunegaran 1896-1944. Jakarta: Penerbit Buku Kompas.

\section{Copyright holder:}

Kinayung Syafira Aratuza (2021)

First publication right:

Syntax Literate: Jurnal Ilmiah Indonesia

This article is licensed under:

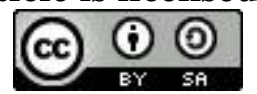

